\title{
Synthesis of $\left[{ }^{3} \mathrm{H}\right]$ DNA Complementary to Ovalbumin Messenger RNA: Evidence for Limited Copies of the Ovalbumin Gene in Chick Oviduct
}

\author{
(estrogen/hybridization/RNA-directed DNA polymerase)
}

\author{
STEPHEN E. HARRIS, ANTHONY R. MEANS, WILLIAM M. MITCHELL*, AND BERT W. O'MALLEY
}

Department of Cell Biology, Baylor College of Medicine, Houston, Texas 77025; and * Department of Microbiology, Vanderbilt University School of Medicine, Nashville, Tennessee 37232

Communicated by Sidney P. Colowick, August 16, 1973

\begin{abstract}
Accumulation of ovalbumin messenger RNA in chick oviduct is absolutely dependent upon estrogen. After estrogen treatment, ovalbumin comprises 60$65 \%$ of the total oviduct protein. We used maximally stimulated animals to extract and partially purify the ovalbumin messenger RNA. The final product was enriched about 100-fold in activity with respect to this specific messenger RNA. This ovalbumin messenger RNA fraction was used to direct the synthesis of a complementary $\left[{ }^{3} \mathrm{H}\right]$ W $A$ in the presence of RNA-dependent DNA polymerase isolated from avian myeloblastosis virus. The complementary $\left[{ }^{3} \mathrm{H}\right] \mathrm{DNA}$ (specific radioactivity, $8 \times 10^{7} \mathrm{cpm} / \mu \mathrm{g}$ ) was a faithful transcript since about $90 \%$ would hybridize back to the original messenger RNA template. Ovalbumin complementary $\left[{ }^{3} H\right] D N A$ was reannealed with an excess of chick-oviduct total DNA. The kinetics of this reaction indicate that only one copy of the ovalbumin gene exists in each haploid genome. These data suggest that estrogen may affect the oviduct genome to stimulate production of large numbers of ovalbumin messenger RNA molecules from a single copy of the ovalbumin gene.
\end{abstract}

Chick oviduct is an excellent model system for studying the mechanism of action of steroid hormones (1). Continuous administration of estrogen to unstimulated chicks results in marked growth and differentiation of the oviduct and the de novo synthesis of the major egg-white protein, ovalbumin. In the fully differentiated oviduct, ovalbumin accounts for over $60 \%$ of the total intracellular protein.

We recently reported that during continued estrogenic stimulation, an excellent correlation exists between intracellular levels of ovalbumin in oviduct and ovalbumin mRNA activity (2). In this instance, mRNA activity was quantified in a rabbit-reticulocyte lysate translation system $(2,3)$. Similarly, by studying the rate of ovalbumin synthesis in vivo after a single injection of estrogen and the concentration of extractable mRNA activity as measured by the reticulocyte cell-free system, a correlation was demonstrated between the extractable mRNA activity and net intracellular translation of ovalbumin mRNA (3).

In most eukaryotic cells the DNA is made up of both repetitive sequences and sequences that are present only once per haploid genome (4). In order to understand the mechanisms of genetic regulation in the eukaryotic genome, it is important to determine whether mRNA for a specific protein is transcribed from repetitive or unique-sequence DNA. In this way we may

Abbreviations: cDNA, complementary DNA; AMV, avian myeloblastosis virus; Cot, product of the concentration of nucleotide sequences of DNA and time of incubation $(\mathrm{mol} \cdot \mathrm{sec} / \mathrm{liter})$. also determine whether gene amplification may play a role in the synthesis of large amounts of a given gene product. To this end, it has been observed that radioactive DNA complementary to purified globin mRNA could be synthesized by use of oncogenic viral RNA-directed DNA polymerase $(5,6)$. This DNA complement of globin mRNA has successfully been used to determine the reiteration frequency of globin genes $(7,8)$ as a genetic probe for quantifying globin RNA sequences during erythroid cell differentiation (9) and to define the existence of globin mRNA sequences in high-molecular-weight nuclear RNA (10).

In the present study we used partially purified ovalbumin mRNA from chick oviduct as a template for RNA-directed DNA polymerase prepared from avian myeloblastosis virus. The radioactive DNA complement (cDNA) of ovalbumin mRNA synthesized in this reaction was then used to examine the reiteration frequency of the ovalbumin gene in estrogenstimulated chick oviduct by annealing the $\mathrm{c}\left[{ }^{3} \mathrm{H}\right] \mathrm{DNA}$ with a vast excess of whole oviduct DNA.

\section{METHODS AND MATERIALS}

Preparation and Purification of $R N A$. Total RNA was extracted from mature hen oviduct, and the ovalbumin mRNA fraction was partially purified by adsorption of poly(adenylic acid)-rich RNA to Millipore filters $(11,12)$. The RNA was eluted from the Millipore filters (11) and then fractionated on $0.3-1.0 \mathrm{M}$ sucrose gradients containing $0.1 \mathrm{M}$ $\mathrm{NaCl}, 1 \mathrm{mM}$ EDTA, and $0.01 \mathrm{M}$ sodium acetate ( $\mathrm{pH}$ 5.0). About $500 \mu \mathrm{g}$ of poly(A)-rich RNA was applied per gradient and centrifuged at $32,000 \mathrm{rpm}$ for $16 \mathrm{hr}$ at $2^{\circ}$ in a Beckman $\mathrm{SW}-40$ rotor. The contents of the centrifuge tubes were fractionated and the fractions were assayed for ovalbumin mRNA activity in the reticulocyte lysate system as described (12). The bulk ovalbumin mRNA activity was found in the 17-19S region of the gradient and represented about $15 \%$ of the RNA mass that was applied to the gradient.

For additional purification, the 17-19S RNA recovered from the sucrose gradient was again adsorbed to Millipore filters as above, except that at this point only 100-150 $\mu \mathrm{g}$ was applied per filter. About $30 \%$ of this RNA fraction was adsorbed, but greater than $85 \%$ of the total ovalbumin mRNA activity was recovered from the filter (19).

DNA Was Prepared from chick oviduct and Escherichia coli essentially as described by Marmur (13), followed by further purification with RNase, $\alpha$-amylase, and Pronase $(20,21)$. The 
DNA was then sheared by two passages through a French pressure cell at $16,000 \mathrm{lbs}$./ inch $^{2}$ to fragments about 400 nucleotides in length. The sheared DNA was then passed through a Chelex 100 column and precipitated with 2 volumes of $95 \%$ ethanol. The final DNA was dissolved in $0.5 \mathrm{mM}$ EDTA.

Purification of Polymerase from Avian Myeloblastosis Virus $(A M V)$. AMV was purified from chick plasma by discontinuous glycerol gradients followed by isopycnic centrifugation in sucrose (14). The RNA-directed DNA polymerase was purified to the DEAE-cellulose step of Kacian et al. (14). The virus was first lysed in $7 \%$ Nonidet $\mathrm{P}-40,0.5 \mathrm{M} \mathrm{KCl}$, and $10 \mathrm{mM}$ dithiothreitol. After centrifugation at $10,000 \mathrm{rpm}$ for $10 \mathrm{~min}$, the supernatant sample was diluted 10 -fold with $0.01 \mathrm{M}$ potassium phosphate (pH 7.2), $2 \mathrm{mM}$ dithiothreitol, and $10 \%$ glycerol (potassium phosphate buffer). This solution was then applied to a DEAE-cellulose column (DE-52, Whatman) previously equilibrated in $0.01 \mathrm{M}$ potassium phosphate buffer. The column was eluted with $80 \mathrm{ml}$ of $0.05 \mathrm{M}$ potassium phosphate buffer followed by $0.3 \mathrm{M}$ potassium phosphate buffer. Fractions were monitored for polymerase activity by a procedure (14) which used poly(A)-oligo(dT) as template. The major peak of enzyme activity eluted just before the main protein peak in the $0.3 \mathrm{M}$ potassium phosphate buffer. This peak was collected, adjusted to $10 \mathrm{mM}$ dithiothreitol, and $50 \%$ glycerol and stored at $-20^{\circ}$. At this point, the RNA-directed DNA polymerase activity was about 100 -fold purified over the activity in the lysed virus. This enzyme preparation could not use poly $(\mathrm{dA})$-oligo $(\mathrm{dT})$ as a template and, therefore, was unlikely to be contaminated with other DNA polymerases.

Assay of RNA-Directed DNA Synthesis with AMV Polymerase and Oviduct $R N A$. The complete reaction mixture of $0.2 \mathrm{ml}$ contained the following components: $50 \mathrm{mM}$ Tris $\cdot \mathrm{HCl}$ (pH 8.3), $10 \mathrm{mM}$ dithiothreitol, $6 \mathrm{mM} \mathrm{MgCl}_{2}, 30 \mathrm{mM} \mathrm{NaCl}$, $20 \mu \mathrm{g} / \mathrm{ml}$ of actinomycin D, $0.25 \mathrm{mM} \mathrm{dCTP}, 0.25 \mathrm{mM}$ dATP, $0.25 \mathrm{mM}$ TTP, $9 \mu \mathrm{M}\left[{ }^{3} \mathrm{H}\right] \mathrm{dGTP}(1500 \mathrm{cpm} / \mathrm{pmol}), 1 \mu \mathrm{g}$ of oligo(dT) $)_{12-18}, 2 \mu \mathrm{g}$ of RNA, and $7.2 \mu \mathrm{g}$ of purified AMV polymerase. Ribonuclease treatment consisted of preincubating an RNA sample in $2 \mathrm{mM}$ Tris $\cdot \mathrm{HCl}(\mathrm{pH} 7.4)$ for $60 \mathrm{~min}$ with $13 \mu \mathrm{g} / \mathrm{ml}$ of RNase T1 (5000 units/ $\mu \mathrm{g}$ ) and $66 \mu \mathrm{g} / \mathrm{ml}$ of RNase A. After a 60 -min incubation at $37^{\circ}$, the reaction was stopped by addition of $2 \mathrm{ml}$ of $10 \%$ trichloroacetic acid containing $0.1 \mathrm{M}$ sodium pyrophosphate and $50 \mu \mathrm{g}$ of bovineserum albumin. Precipitates were collected on cellulose nitrate filters (Millipore HAWP) and thoroughly dried under an infrared lamp. Radioactivity was determined by counting in a scintillation fluid composed of Spectrofluor-toluene (Amersham-Searle). Counting efficiency for tritium was $25 \%$ in a Beckman LS-250 scintillation spectrometer.

Production and Purification of $c\left[{ }^{3} H\right] D N A$. In order to produce a cDNA with high specific activity from ovalbumin mRNA fractions, the conditions of the AMV-polymerase reaction had to be modified. Complementary DNA (cDNA) to mRNA was produced with the viral polymerase and three of the four deoxynucleoside triphosphates, all labeled with tritium at $11.7 \mathrm{Ci} / \mathrm{mmol}$. This reaction mixture contained in a final volume of $1 \mathrm{ml}: 50 \mathrm{mM}$ Tris $\cdot \mathrm{HCl}(\mathrm{pH} 8.3), 10 \mathrm{mM}$ dithiothreitol, $6 \mathrm{mM} \mathrm{MgCl}, 30 \mathrm{mM} \mathrm{NaCl}, 20 \mu \mathrm{g} / \mathrm{ml}$ of actinomycin D, $21 \mu \mathrm{M}\left[{ }^{3} \mathrm{H}\right] \mathrm{dCTP}, 21 \mu \mathrm{M}\left[{ }^{3} \mathrm{H}\right] \mathrm{dATP}, 21$ $\mu \mathrm{M}\left[{ }^{3} \mathrm{H}\right] \mathrm{TTP}$, and $25 \mu \mathrm{M}$ dGTP. Also included in the reactions were: $11 \mu \mathrm{g}$ of mRNA, $5 \mu \mathrm{g}$ of oligo $(\mathrm{dT})_{12-18}, 36 \mu \mathrm{g}$ of AMV polymerase, and $100 \mu \mathrm{g}$ of bovine-serum albumin. Under these conditions the $\mathrm{cDNA}$ will have a theoretical specific radioactivity of $8 \times 10^{7} \mathrm{cpm} / \mu \mathrm{g}$ under the counting conditions used in our laboratory and assuming that each nucleotide is incorporated equally.

Samples were incubated at $20^{\circ}$ for $60 \mathrm{~min}$ and then adjusted to an EDTA concentration of $2 \mathrm{mM}$. E. coli DNA $(100 \mu \mathrm{g})$ was added as carrier and the entire sample was placed on a Sephadex G-50 column equilibrated with $0.1 \mathrm{M} \mathrm{NaCl}$. The excluded fraction was collected from the column and $E$. coli DNA was added to a concentration of $100 \mu \mathrm{g} / \mathrm{ml}$. This mixture was then precipitated with 2 volumes of cold $95 \%$ ethanol.

Distribution of $c D N A$ on Alkaline Sucrose Gradients. The precipitate described above was dissolved in $1 \mathrm{ml}$ of $0.9 \mathrm{M}$ $\mathrm{NaCl}-0.1 \mathrm{~N} \mathrm{NaOH}-5 \mathrm{mM}$ EDTA and heated at $60^{\circ}$ for 5 min. The samples were then layered on a linear 38-ml 5-25\% (w/w) sucrose gradient in $0.9 \mathrm{M} \mathrm{NaCl}-0.1 \mathrm{~N} \mathrm{NaOH}-5 \mathrm{mM}$ EDTA, prepared in polyallomer tubes. Cellulose nitrate tubes were unsatisfactory due to the alkali. Chick-oviduct DNA sheared in a French pressure cell to 400 nucleotide lengths was dissolved in this same solution and centrifuged in a parallel gradient to serve as a sedimentation marker. Samples were centrifuged in an SW27 Beckman rotor for $44 \mathrm{hr}$ at $20^{\circ}$. Gradients were fractionated from bottom to top, and the average molecular weight of the cDNA fractions and the marker DNA were calculated by the method of Studier (15) from the $\mathrm{S}$ values as determined by the method of McEwen (16). Fractions containing cDNA were neutralized to $\mathrm{pH} 7.0$ and precipitated by addition of 2 volumes of cold $95 \%$ ethanol. Precipitates were collected by centrifugation, dissolved in $0.5 \mathrm{mM}$ EDTA, and stored at $-20^{\circ}$.

Hybridization of $c\left[{ }^{3} H\right] D N A$ to Oviduct $m R N A$. To test the fidelity of the enzymatic transcription of the RNA template, cDNA was back-hybridized to the mRNA fraction used as template. About $1 \times 10^{-4} \mu \mathrm{g}$ of $\mathrm{c}\left[{ }^{3} \mathrm{H}\right] \mathrm{DNA}$ was mixed with $0.05-2.0 \mu \mathrm{g}$ of mRNA in $0.48 \mathrm{M}$ sodium phosphate buffer $(\mathrm{pH}$ 6.8 ) in a total volume of $50 \mu \mathrm{l}$. Tubes were sealed, heated for 5 min at $100^{\circ}$, and incubated for $24 \mathrm{hr}$ at $60^{\circ}$. The contents of each tube were then diluted to $0.03 \mathrm{M}$ phosphate buffer and fractionated on hydroxylapatite columns (1 ml), which had been equilibrated at $60^{\circ}$. Single-stranded DNA and RNA was eluted with $10 \mathrm{ml}$ of $0.12 \mathrm{M}$ phosphate buffer, whereas the double-stranded hybrids were eluted with $10 \mathrm{ml}$ of $0.48 \mathrm{M}$ phosphate buffer (17).

Annealing of $c\left[{ }^{3} H\right] D N A$ to DNA Under Conditions of Excess Chick-Oviduct DNA. Excess chick-oviduct DNA sheared to 400 nucleotide lengths ( $3.0 A_{260}$ units) was mixed with $3 \times$ $10^{-5} \mu \mathrm{g}$ of $\mathrm{c}\left[{ }^{3} \mathrm{H}\right] \mathrm{DNA}$. Samples were placed in tubes which were sealed, heated $5 \mathrm{~min}$ at $100^{\circ}$, and incubated for various periods of time at $60^{\circ}$. Reactions were terminated by diluting the contents of the sealed tubes to $0.03 \mathrm{M}$ phosphate buffer and applying these samples to hydroxylapatite columns $(2 \mathrm{ml})$ equilibrated at $60^{\circ}$ with $0.03 \mathrm{M}$ phosphate buffer. Singlestranded DNA was eluted with $0.12 \mathrm{M}$ phosphate buffer, and 15 fractions of $1.35 \mathrm{ml}$ per fraction were collected. Doublestranded material was eluted with $0.48 \mathrm{M}$ phosphate buffer. Again, 15 fractions of $1.35 \mathrm{ml}$ per fraction were collected. One milliliter of each fraction was taken for determination of radioactivity, and the remainder of each fraction for determination of $A_{260}$. 

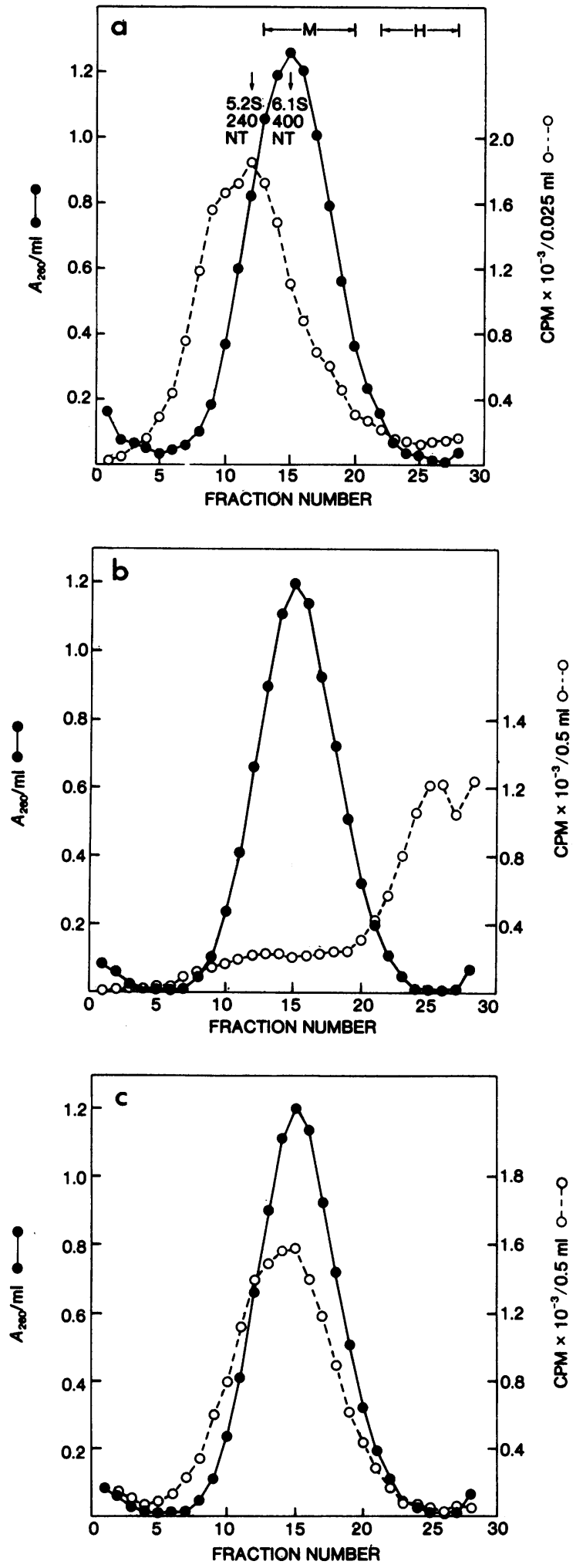

Fig. 1. Alkaline sucrose gradients of $c\left[{ }^{3} \mathrm{H}\right] \mathrm{DNA}$. After the reaction mixture for production of a cDNA of high specific activity was freed of labeled deoxynucleoside triphosphates, the product was analyzed on alkaline sucrose gradients $(a) . N T=$ nucleotides. Two fractions were collected, as indicated by the $M$ and $H$ regions. (b) An alkaline sucrose gradient of the $\mathrm{H}$ fraction; (c) an alkaline sucrose gradient of the $M$ fraction. ( $\bullet$ chick-oviduct DNA used as marker; $(O) \mathrm{cDNA}$. Numbers on the right-hand ordinates have been multiplied by $10^{-3}$.

\section{RESULTS}

Synthesis of DNA Complementary to Ovalbunin mRNA. Production of cDNA by the 17-19S mRNA fraction (see Methods) is almost completely dependent on addition of oligo(dT) to the reaction system containing the viral RNA-dependent DNA polymerase (Table 1). This finding indirectly confirms the presence of poly(A) on the ovalbumin mRNA fraction since oligo(dT), by apparently hydrogen bonding to the poly(A)-region of the RNA molecule, serves as an effective primer for transcription of mRNA into DNA by the viral polymerase. Moreover, the reaction system is completely dependent on addition of template (Table 1). In addition, if the RNA template is pretreated with RNase, little or no synthesis is observed.

Actinomycin D prevents double-stranded DNA synthesis when the viral polymerase is used with RNA templates (18). Considerably more product is made when actinomycin $\mathrm{D}$ is omitted from the reaction system (Table 1). This is presumably due to DNA - DNA synthesis from the initial RNA - DNA product. Thus, actinomycin $\mathrm{D}$ was included in the reaction system for the production of a single-stranded $\mathrm{cDNA}$ of high specific activity of the 17-19S ovalbumin mRNA fraction.

Characterization of the $c\left[{ }^{3} \mathrm{H}\right] D N A$ Product. After incubation of the mRNA fraction with RNA-directed DNA polymerase and ${ }^{3} \mathrm{H}$-labeled deoxynucleoside triphosphates, excess labeled triphosphates were removed from the DNA product by Sephadex G-50 chromatography. The DNA product was then freed of RNA by alkaline treatment of the sample and analyzed on alkaline sucrose gradients. The cDNA is heterogeneous in size with an average sedimentation coefficient of $5.2 \mathrm{~S}$ (Fig. 1a). This corresponds to about 240 nucleotides. Chick-oviduct DNA sheared to about 400 nucleotide lengths was included in a parallel alkaline sucrose gradient as marker.

Two fractions from the alkaline gradient of the cDNA were collected ( $\mathrm{M}$ and $\mathrm{H}$ regions, Fig. $1 a$ ). These $\mathrm{M}$ and $\mathrm{H}$ fractions were neutralized and precipitated with ethanol, and an aliquot of each was again analyzed on alkaline sucrose gradients. Chick-oviduct DNA (400 nucleotides) was included in each gradient as marker. Some high-molecular-weight cDNA is being made in the reaction system (800-1600 nucleotides) (Fig. 1b). Although this material represents a small portion of the total product, it should be possible to collect material the exact size of the complete ovalbumin gene (minimum of 1161 nucleotides necessary to code for the 387 amino acids of a single ovalbumin chain).

Fig. $1 c$ represents an aliquot of the $M$ fraction centrifuged through alkaline gradients with sheared oviduct DNA. This fraction of the cDNA has an average size of 400 nucleotides, very close to that of the sheared oviduct DNA. This fraction

TABLE 1. Requirements for DNA synthesis with ovalbumin messenger RNA as template

\begin{tabular}{cc}
\hline Reaction mixture & $\begin{array}{c}\text { pmol of dGMP } \\
\text { incorporated } / 60 \mathrm{~min}\end{array}$ \\
\hline Complete & 3.87 \\
- oligo(dT) & 0.05 \\
- RNA & 0 \\
- Actinomycin D & 15.25 \\
+ RNase & 0.05 \\
\hline
\end{tabular}


of the cDNA, containing 400 nucleotides, was used in the subsequent hybridization and annealing experiments.

Back-Hybridization of $c\left[{ }^{3} H\right] D N A$ to $18 S$ Ovalbumin $m R N A$ Fraction. To ensure that the viral polymerase catalyzes the synthesis of a faithful DNA copy, the DNA product was backhybridized with the ovalbumin mRNA fraction used as template. Nearly complete annealing occurs (80-90\%) when the DNA product is hybridized to excess ovalbumin mRNA (Fig. 2). When the putative hybrid is diluted to low ionic strength (0.03 M phosphate buffer) and treated with RNase, one observes almost complete destruction of the hybrid material $(93 \%)$.

$c\left[{ }^{3} H\right] D N A$ Annealing in Oviduct DNA Excess. Fig. 3 represents the kinetics of annealing of single-stranded $\mathrm{c}\left[{ }^{3} \mathrm{H}\right]-$ DNA to total oviduct DNA. Fig. $3 a$ represents the kinetics of reannealing of total chick-oviduct DNA. About $30 \%$ of the total DNA reanneals at low Cot values and represents the repeated sequences in the chick genome. The remaining $70 \%$ of the chick DNA is composed of the more slowly reannealing unique or single-copy sequences (21). From Fig. $3 a$, the Cot $_{1 / 2}$ of the total DNA can be calculated to be 320 . Moreover, at a Cot of 5000 about $90 \%$ of the total DNA has reassociated. The $\mathrm{Cot}_{1 / 2}$ of single-copy DNA sequences present in total DNA can now be calculated to be 660 . Thus, if single-copy DNA was separated from repetitive sequences, its predicted Cot $_{1 / 2}$ would be 460 (i.e., $0.7 \times 660$ ) $\dagger$.

The annealing of the cDNA to excess oviduct DNA is represented by Fig. $3 b$. At a Cot of $5000,70 \%$ of $c\left[{ }^{3} \mathrm{H}\right] \mathrm{DNA}$ formed stable duplexes with the excess oviduct DNA. Assuming that the ovalbumin gene is about 1200 nucleotides in length, a single copy per halpoid genome occupies about $1.0 \times$ $10^{-6}$ fractionally of the total genome. Under the experimental conditions used, unlabeled DNA was in a $2.3 \times 10^{6}$ by weight excess, yielding an expected $70 \%$ annealing at high Cot values, (i.e., radioactive and unlabeled cDNA competing for the same site) in agreement with that found experimentally. Furthermore, the cDNA annealed with the chick DNA with an apparent $\operatorname{Cot}_{1 / 2}$ of 480 . This value is quite close to the value predicted for single-copy chick DNA (460) under our experimental conditions.

\section{DISCUSSION}

Partially purified ovalbumin mRNA was used in the presence of viral RNA-dependent DNA polymerase to direct the synthesis of a complementary DNA copy of high specific radioactivity. This cDNA was shown to represent a faithful copy of the mRNA. Annealing the $c\left[{ }^{3} \mathrm{H}\right] D N A$ to an excess of chickoviduct DNA provides evidence that only a single copy of the ovalbumin gene is present in each haploid chick genome.

The ovalbumin mRNA used in these experiments was partially purified from oviducts of estrogen-stimulated chicks.

$\dagger$ An independent estimate of the expected Cot $_{1 / 2}$ for chick uniquesequence DNA can be derived from a knowledge of the content of haploid DNA per chick cell $(1.3 \mathrm{pg}$, ref. 22$)$ and the observed Cot Co $_{1 / 2}$ for unique-sequence $E$. coli DNA (3, ref. 23) and its genome size $\left(4.5 \times 10^{6}\right.$ nucleotide pairs, ref. 24$)$. Using a value of 0.7 for the fraction of unique sequences in chick DNA, we would expect about $9 \times 10^{8}$ unique-sequence nucleotide pairs. Since the rate constant $(K)$ for reassociation is inversely proportional to the genome complexity $(G)$, then $K_{1} G_{1}=K_{2} G_{2}$, yielding a $\operatorname{Cot}_{1 / 2}$ of about 600 for unique-sequence chick DNA.

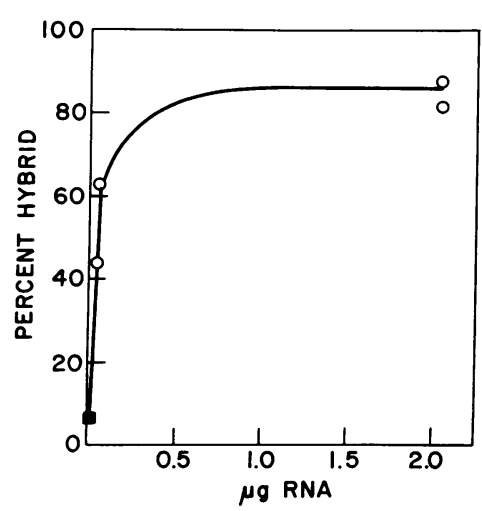

Fig. 2. Back-hybridization of $c\left[{ }^{3} \mathrm{H}\right] \mathrm{DNA}$ to the $17-19 \mathrm{~S}$ ovalbumin mRNA fraction. About $1 \times 10^{-4} \mu \mathrm{g}$ of $\mathrm{c}\left[{ }^{3} \mathrm{H}\right] \mathrm{DNA}$ was mixed and hybridized with various concentrations of mRNA as given in Methods (O-O). The amount of single- and doublestranded material was determined by hydroxylapatite chromatography. As indicated by the closed square, when the hybrid is diluted to low ionic strength ( $0.03 \mathrm{M}$ phosphate buffer) and treated with RNase, over $90 \%$ of the hybrid is destroyed, as assayed by hydroxylapatite.

The purification steps included adsorption to Millipore filters, sucrose gradient centrifugation, and readsorption of the 1719S fraction to Millipore filters. The relative quantity of ovalbumin mRNA at various steps during the purification procedure was assayed by the ability of the RNA to direct the synthesis of authentic ovalbumin in a cell-free proteinsynthesizing system and also by the analysis of the content of poly(adenylic acid) $(12,19)$. By these criteria the ovalbumin mRNA used in the studies reported here was purified some 100 -fold in activity with respect to total chick RNA. Assessment of the absolute level of purity for this mRNA fraction is difficult. Relative to poly(A)-containing RNA sequences in the chick oviduct, it may be as much as $90 \%$ pure ovalbumin mRNA. This argument is based on the fact that in the chick oviduct as much as $60 \%$ of the protein made is ovalbumin, and one would thus predict a high concentration of ovalbumin

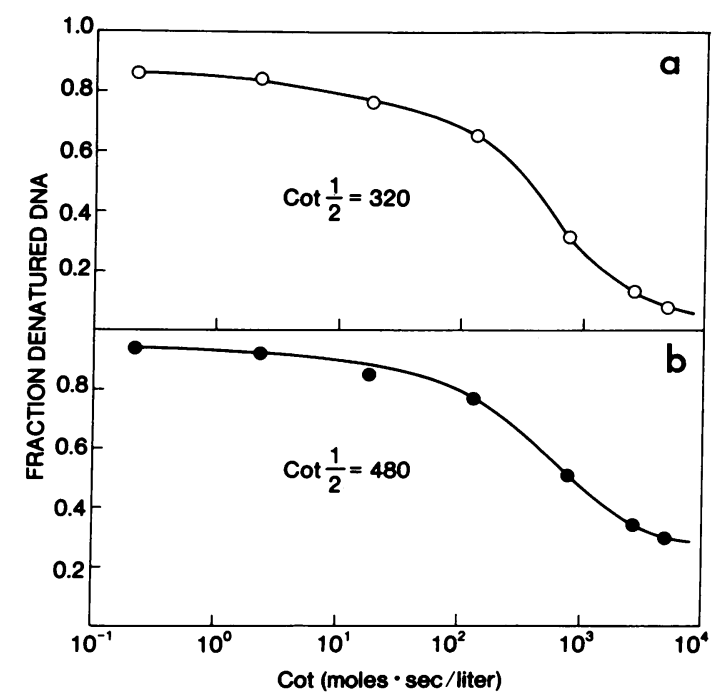

Fig. 3. Annealing of $\left.\mathrm{c}^{3} \mathrm{H}\right] \mathrm{DNA}$ to DNA under conditions of excess of chick-oviduct DNA. (a) (O) Reannealing of the total chick DNA, as assayed by $A_{260 \mathrm{~nm}}(20,21)$. (b) (๑) Annealing kinetics of the $\left[{ }^{3} \mathrm{H}\right] \mathrm{DNA}$ to the total chick-oviduct DNA. 
mRNA as compared to other mRNAs in the initial RNA extract (1). The major contaminating RNA in terms of mass in the final preparation is most likely $18 \mathrm{~S}$ ribosomal RNA and other ribosomal RNA fragments. Nevertheless, for the purpose of synthesizing complementary DNA to ovalbumin mRNA, the ribosomal RNA is not a major obstacle since ribosomal RNA is a poor template for AMV-polymerase and, in addition, is not enhanced as a template by the addition of oligo(dT) (5). Finally, if [ $\left.{ }^{3} \mathrm{H}\right] \mathrm{DNA}$ complementary to ribosomal RNA was made in significant quantities, the $c\left[{ }^{3} \mathrm{H}\right] \mathrm{DNA}$ fraction would anneal to the intermediate repetitive DNA sequences (19)

Analysis of the kinetics of the annealing of $c\left[{ }^{3} \mathrm{H}\right] \mathrm{DNA}$ to total chick DNA reveals the possibility that the ovalbumin gene is represented only once in each haploid genome. The limitation of this interpretation depends mainly on the purity of our ovalbumin mRNA fraction used as template for the AMV-polymerase. However, with this limitation in mind, our studies suggest that the mechanism by which estrogen induces the synthesis and accumulation of ovalbumin probably does not involve gene amplification. Instead, estrogen affects the chick-oviduct genome in such a way as to stimulate production of large numbers of ovalbumin mRNA molecules from a single copy of the ovalbumin gene. A less likely possibility is that multiple copies of the ovalbumin gene exist but may be cytoplasmic (i.e., episomal DNA). Since these copies would not be integrated into the nuclear DNA they might be lost during extraction.

Of all the other poly(A)-containing mRNAs studied in eukaryotic systems, the globin mRNA is probably the best characterized. Again, the DNA complement of globin mRNA appears to anneal in experiments with vast DNA excess with kinetics indicating limited or single copies of the globin gene in the genome $(7,8)$. In addition, the $c\left[{ }^{3} \mathrm{H}\right] \mathrm{DNA}$ of duck-globin mRNA has successfully been used as a genetic probe to detect the presence of globin mRNA sequences in giant heterogeneous nuclear RNA (10). To date, this is probably the most convincing evidence for a relationship between giant heterogeneous nuclear RNA and a specific cytoplasmic mRNA. We hope to use this high-specific-activity $c\left[{ }^{3} \mathrm{H}\right] \mathrm{DNA}$ as a probe for studying early estrogen induction of ovalbumin messenger in chick oviduct. This probe should allow elucidation of the kinetics of heterogeneous RNA synthesis in the nucleus, its subsequent processing, and the appearance of ovalbumin mRNA in the cytoplasm.
This work was supported in part by the following research grants: BC-101 from the American Cancer Society; HD-04473, HD-05797, and AM 10833 from the National Institutes of Health; and 630-0141 from the Ford Foundation. Chick plasma containing avian myeloblastosis virus was the generous gift of Dr. J. W. Beard of Duke University through a contract with the Virus Cancer Program of the National Cancer Institure (Dr. M. A. Chirigos, Contract Officer). A.R.M. and W.M.M. are recipients of Research Career Development Awards from the National Institutes of Health.

1. O'Malley, B. W., McGuire, W. L., Kohler, P. O. \& Korenman, S. G. (1969) Recent Progr. Horm. Res. 25, 105-160.

2. Comstock, J. P., Rosenfeld, G. C., O'Malley, B. W. \& Means, A. R. (1972) Proc. Nat. Acad. Sci. USA 69, 2377-2380.

3. Chan, L., Means, A. R. \& O'Malley, B. W. (1973) Proc. Nat. Acad.Sci. USA 70, 1870-1874.

4. Britten, R. J. \& Davidson, E. H. (1971) Quart. Rev. Biol. 46, 111-138.

5. Verma, I. M., Temple, G. F., Fan, H. \& Baltimore, D. ( 972) Nature New Biol. 235, 163-167.

6. Ross, J., Aviv, H., Scolnick, E. \& Leder, P. (1972) Proc. Nat. Acad. Sci. USA 69, 264-268.

7. Harrison, P. R., Hell, A., Birnie, G. D. \& Paul, J. (1972) Nature 239, 219-221.

8. Packman, S., Aviv, H., Ross, J. \& Leder, P. (1972) Biochem. Biophys. Res. Commun. 49, 813-819.

9. Ross, J., Ikawa, Y. \& Leder, P. (1972) Proc. Nat. Acad. Sci. USA 69, 3620-3623.

10. Imaizumi, T., Diggelmann, H., Scherrer, K. (1973) Proc. Nat. Acad. Sci. USA 70, 1122-1126.

11. Rosenfeld, G. C., Comstock, J. P., Means, A. R. \& O'Mal'ey, B. W. (1972) Biochem. Biophys. Res. Commun. 46, 16951703.

12. Means, A. R., Comstock, J. P., Rosenfeld, G. C. \& O'Malley, B. W. (1972) Proc. Nat. Acad. Sci. USA 69, 1146-1150.

13. Marmur, J. (1961) J. Mol. Biol. 3, 208-218.

14. Kacian, D. L., Watson, K. F., Burny, A. \& Spiegelman, S. (1971) Biochim. Biophys. Acta 246, 365-383.

15. Studier, W. F. (1965) J. Mol. Biol. 11, 373-390.

16. McEwen, C. R. (1967) Anal. Biochem. 20, 114-149.

17. Britten, R. J. \& Smith, J. (1970) Carnegie Inst. Washington Yearb. 68, 378.

18. Ruprecht, R. M., Goodman, N. C. \& Spiegelman, S. (1973) Biochim. Biophys. Acta 294, 192-203.

19. Rosen, J., Harris, S. E., Rosenfeld, G. C. \& O'Malley, B. W. (1974) Cell Differentiation, submitted.

20. Liarakos, C., Rosen, J. M. \& O'Malley, B. W. (1973) Biochemistry 12, 2809-2816.

21. Rosen, J., Liarakos, C. \& O'Malley, B. W. (1973) Biochemistry 12, 2803-2809.

22. Herbert A. Sober, ed. (1970) Handbook of Biochemistry (The Chemical Rubber Co.), 2nd ed., pp. H-111.

23. Britten, R. J. \& Kohne, D. E. (1968) Science 161, 529.

24. Cairns, J. (1962) J. Mol. Biol. 4, 407. 